\title{
High School Government Students Outdo the Pundits
}

\author{
Theresa Gubicza, APSA
}

When The Washington Post invited a group of $10^{\text {th }}$ grade students from Montgomery Blair High School in Silver Spring, Maryland to enter its ninth Crystal Ball contest, it probably never expected the students would predict the outcome of the November 1998 elections more accurately than 13 other contestants, most of whom were professional political pundits.

The outcome surprised Stacy Ferrar Dimmick, the students' National, State and Local Government teacher, as well. When Dimmick's class first participated in 1996, it accurately predicted the popular and electoral vote in the presidential election, but was not as successful predicting the outcome of the House and Senate races. This time, Dimmick and her 71 students took a very thorough approach to predicting the outcome. Each student selected one of the more competitive gubernatorial, senate, or house races and examined its campaign ads, top issues, and local media coverage, as well as the district's demographics and voting trends. Each student then predicted their race's outcome. When the students compiled their predictions, they predicted what the pundits had not: there would be no Republican gains in the House of Representatives. The ouse outcome proved to be the deciding factor in the contest.

Dimmick credits much of the students' success in the contest to their participation in the honors level, interdisciplinary Communication Arts Program (CAP), which links the disciplines of Social Studies, English, Journalism, and Broadcasting. Dimmick and her CAP colleagues, Maureen Diodati, John Mathwin, and John Goldman, collaborate on many of their teaching duties. Dimmick says that this teamwork makes them stronger, more creative teachers and enhances the students' classroom experience. When the CAP students staged a mock congress in Dimmick's class earlier this year, they debated the issues in Diodati's English class. Goldman's lessons on media literacy informed their analysis of campaign ads and their journalism experience reminded them to consider media bias as a factor when using newspaper articles to research their races.

According to Dimmick, most students at Blair have an interest in government and politics, but the CAP students have a particularly strong interest. Dimmick attributes the students' interest in part to Silver Spring's proximity to Washington, DC, and to the fact that many of the students' parents have careers related to politics and government. Dimmick takes advantage of these factors by inviting the professionals to share their expertise. Students enjoy class visits from state legislators, newspaper columnists, and lobbyists. Lawyers instruct students on courtroom procedure prior to the annual mock trial. This spring, students will stage a mock Senate impeachment trail. While the students arrive with an interest in politics, Dimmick acknowledges that many times they also arrive with a liberal bias. Dimmick simply makes the students aware of this bias. CAP student Michael Erhardt admits that since September, class debates have challenged many of his political views and changed others, but most importantly, have provided the opportunity to consider opposing points of view.

In addition to learning about how government works, students learn to appreciate their role in the political process. A summer assignment to discover three concerns in their community (e.g., a need for traffic signals or crosswalks) becomes a lesson in how change starts with one person. Dimmick invites ordinary people who have impacted government, including a student who successfully petitioned for a statewide bicycle helmet law, to address the students. When her students see that government is close to home, they understand they can have an impact. CAP student Bonnie Gregory said that prior to the program, she never gave politics a second thought, but "studying the political process has shown that participating is important." Now, she and other CAP students see political careers in a new light.

Dimmick, who has been teaching American government for seven years, tries to change and improve her teaching each year. She says that she is constantly learning not only from the other teachers in the CAP program and other social studies teachers at Blair and throughout the school district, but also from her students. Dimmick retains an enthusiasm for her subject. She feels that if she has fun teaching, her students will have fun learning.

Dimmick is proud of her students' success in the Post contest and their attitude since winning. "Winning has proved they can be successful," said Dimmick, and winning "has really spurred them on, they're doing better and better" as the year progresses. 